\title{
Forsking i små helseføretak
}

\author{
Ved Klinikk for psykisk helsevern i Helse Fonna har vi sidan 2003 bygd opp ein forskingsseksjon. \\ Vi trur at erfaringane våre kan vere nyttige også for andre små helseføretak og avdelingar \\ i spesialisthelsetenesta. Langsiktig tenking, fagleg støtte og forskingsnettverk er særs viktig.
}

For små helseføretak kan det å starte med forsking vere ei ekstra stor utfordring. Årsakene til dette er mange, men mangel på fagfolk med forskarkompetanse, lang veg til universitetsmiljøa, den stadige kampen for å fylle spesialiststillingane og generell ressursmangel er nokre grunnar. Det er likevel viktig at dei mindre føretaka er medvitne om kva ansvar dei har for å lage forskingsstrategi og for å produsere forsking i klinikkane sine $(1-4)$. Det er grunnar for at dette lønner seg på sikt.

Då vi ut fra publikasjonsproduksjon (fig 1) meiner vi er på veg til å lykkast i forskingssatsinga vår, ønsker vi i Klinikk for psykisk helsevern i Helse Fonna å dele røynslene våre med leiarar og forskingsinteresserte klinikarar. Ved å bruke vår forskingssatsing som døme ønsker vi å svare på følgjande spørsmål: Korleis kan leiinga i eit mindre helseføretak eller avdeling få til forsking? Korleis skal ein organisere det heile? Kva type ressursar må ein tilføre? På kva måte bør den forskingsinteresserte klinikaren kunne forvente å bli ivaretatt? Kva ringverknader oppstår av forskingsarbeidet i klinikken?

\section{Historikk}

Satsinga på forsking i Klinikk for psykisk helsevern i Helse Fonna starta i 2003 ved at klinikkdirektør oppretta ei halv stilling som forskingskoordinator. Oppgåvene til forskingskoordinatoren var å kartlegge eksisterande forskingsprosjekt i klinikken, formidle kontakt mellom klinikarar og relevante rettleiingskrefter i universitetsmiljø, informere om stipendkjelder og informere om korleis dei forskingsinteresserte skulle gå fram for å finne problemstilling, lage prosjektnettverk og prosjektprotokoll. I 2007 oppretta vi ein eigen forskingsseksjon. Dei to første ph.d.-kandidatane fra klinikken disputerte hausten 2009.

\section{Leiarforankring og organisering}

Vi tenker at leiaren tidleg bør lage forskingsstrategi med tilhøyrande plan for gjennomføring. I den forskingspolitiske strategien må det vere fokus på organisering, løn og tilsetjing. Det er viktig å vere klar over at det tar tid å bygge forsking (5-10 års perspektiv) og at stabilitet i leiinga er ein fordel.

Vi har funne det naudsynt å opprette leiar-, koordinator- og forskingsassistentstillingar i Forskingsseksjonen. Seksjonen har budsjett, prosedyrer for mellom anna internkontroll og rapportering, og eigne lokale. Fagaktiviteten som Forskingsseksjonen driv, kan fungere som mal for andre som ønsker å opprette eit forskingsmiljø:

- Open internundervisning kvar 14. dag med fokus på generell metode og statistikk

- Årleg internseminar med eksterne forskarar

- Begynnarkurs i metode og statistikk

- Lokale forskingsfaglege nettverksmøte

\section{Fagleg støtte og forskingsnettverk}

Våre forskarar er avhengige av den kompetente forskingsfaglege rettleiinga, nettverka, dei faglege kursa, ph.d.-utdanningsprogrammet og forskarskulane som Universitetet i Bergen tilbyr. Alle ph.d.stipendiatane våre har hovudrettleiar med universitet som arbeidsstad.

Då medlemskap i relevante forskingsnettverk er nyttig for å få kontakt med gode rettleiarar og samarbeidspartnarar, og som stipendkjelder, har vi fordra slike medlemskap hos våre tilsette. Lokalt har forskingskoordinator oppretta det opne lågterskel «Fonnanettverket for forsking på mental helse». Dette verkar forskingsstimulerande ved at medlemmene får tilsendt forskingsrelevant informasjon, og ved at medlemmene utgjer eit utval til å rekruttere fra ved behov for bistand ved datainnsamling i klinikken. Vidare er forskarane våre ofte tilknytta større nettverkssatsingar og kompetansesentra i regionen (5).

\section{Forsking og klinisk verksemd}

Kliniske seksjonar bidrar til forskingarbeid ved å avstå klinikarar til Forskingsseksjonen mot frikjøpsmiddel. Når ein tilsett ønsker å forske, krev føretaket at han/ho søker eksterne stipendkjelder før eventuell tildeling av interne forskingsmiddel. At ein klinikar går ut i forskingspermisjon kan $\mathrm{i}$ eit kort perspektiv føre til auka arbeidsbyrde på kollegaer i klinikken. Imidlertid meiner vi at forskingsaktivitet i lengre perspektiv kan bidra til å gi klinikken eit godt omdømme. Nytilsette hos oss har ved fleire høve gitt uttrykk for at mogelegheit til å forske har medverka til at dei begynte i klinikken. I tillegg kjem effektar i form av auka kompetanse og kvalitet på rutiner og behandlingstilbod, når klinikarar bidrar i datainnsamlingsarbeid og systematiske intervensjonar. Forskingsseksjonen bidrar fra si side til fagutvikling i klinikken gjennom kurs, fagseminar og undervisning.

Så kan ein spørje seg: Er det lett for at forsking utført i helseføretak blir dårleg forsking? Svaret kan vere: Dersom forskaren ikkje har tilgong til kompetent rettleiing eller ikkje blir gitt tid til å forske, kan resultatet bli fagleg dårleg eller inga forsking. Vi vil likevel hevde at nærleik til pasientane medfører at klinikarane finn gode, relevante forskingshypoteser, og at datatilgongen er god. Deltids forskarstil-

\section{Ramme 1}

«Oppskrift» på korleis ein kan bygge opp forsking i mindre avdelingar/ helseføretak

Definer forskingsfaglege satsingsområde i samsvar med bestillardokumentet til føretaket

Begynn med koordinatorstilling, seinare forskingsavdeling

Sats på eksterne kjelder for frikjøpsmiddel (regionalt helseføretak)

Kartlegg forskingsaktivitet, motiver forskingsinteresserte til å lage prosjektprotokoll, -nettverk og søke forskingsfrikjøp

Likestill klinisk arbeid og forsking personaladministrativt og lønspolitisk

- Lag organisasjonsstruktur for løns- og personaladministrasjon av klinikarar i forskingsfrikjøp

Gi startfaseordningar for prosjekt $120 \%$ arbeidstid i eitt år til å lage prosjektprotokoll og $50 \%$ til første artikkel)

Knytt forskingsprosjekta opp mot universitet/høgskule (rettleiing) og utanlandske forskingsinstitusjonar med høg og riktig kompetanse

Sats på ph.d.-prosjekt føre mindre prosjekt

Bli god på statistikk og annan metode ved hjelp av kurs, internundervisning, forskingskonferansar og gode rettleiarar

Bruk/skap forskingsnettverk (NB! Også utland)

Tilby godt sosialt/fagleg miljø og synleggjer bidraga til forskarane i klinisk samanheng

Forskingsstrategiar og planar for gjennomføring må vere langsiktige $15-10$ år) 


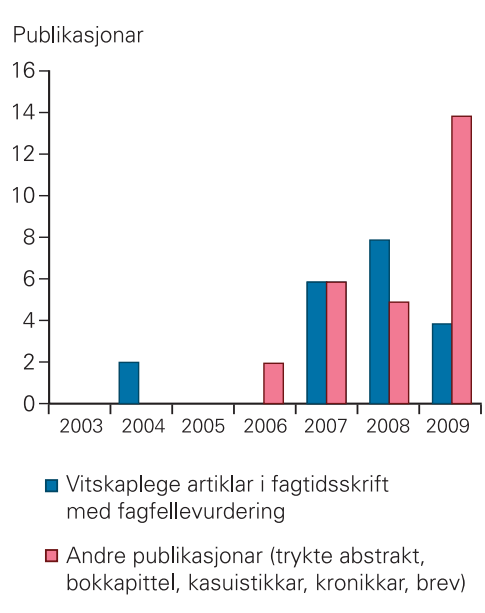

Figur 1 Talet på vitskaplege publikasjonar i satsingsperioden 2003-09, Klinikk for psykisk helsevern, Helse Fonna

lingar og dobbeltkompetanseløp gjer det også mogeleg å gjennomføre longitudinelle studiar med lang oppfølgingstid. Dette er faktorar som er med på å skape relevant forsking av god kvalitet.

\section{Plan og utfordringar framover}

Der er enno nokre «barnesjukdomar» i vår organisasjon når det gjeld forsking. Mellom anna manglar vi gode nok rutinar på føretaksnivå når det gjeld løns- og personaladministrative forhold, og det er vanskeleg å finne gode vikarar i kliniske seksjonar når tilsette søker permisjon for å forske. Problemet med «lønsgapet» mellom klinisk arbeid og forsking er der fortsatt, trass i mogelegheit for klinisk arbeid i vakt eller deltid parallelt med forsking.

Etter ein «stimulerings- og oppbyggingsfase» over seks år ønsker vi nå å vidareutvikle forskingssatsinga ved å ivareta kompetanse på postdoktornivå, å opprette to nye «doppeltkompetanse»-stillingar for psykologar innan rus og å stimulere til forsking utført av høgskoleutdanna grupper som sjukepleiarar, sosionomar, ergoterapeutar m.v. Spissing av tematisk fokus vil vi gjere etter føringar gitt i bestillardokumenta. Mellom anna følger vi opp i forskingssatsinga til Helse Fonna «Nettverk for forsking på behandlingsliner og samhandling i helsetenesta», som er ei forskingssatsing som kombinerer fagleg spissing, lokalt samarbeid, fagleg relevans for verksemda og regionalt og internasjonalt samarbeid. Grunnpilarar for forskingsaktivitet $\mathrm{i}$ eit helseføretak er etter vår meining leiarforankring, fornuftig organisering, økonomisk tilrettelegging for klinikarar, fagleg støtte lokalt og tilgong til kompetente rettleiingskrefter fra universitet eller andre forskings- institusjonar. Vi håpar råda våre (ramme 1) kan vere til nytte for andre småe føretakseiningar som vil forske.

\section{Eva Biringer \\ eva.biringer@helse-fonna.no \\ Miriam Hartveit \\ Oddbjørn Hove \\ Forskingsseksjonen \\ Klinikk for psykisk helsevern \\ Helse Fonna \\ Postboks 2170 \\ 5504 Haugesund}

\section{Anne Lise Kvalevaag}

Klinikk for psykisk helsevern

Helse Fonna

Oppgitte interessekonflikter: Ingen

\section{Litteratur \\ 1. Sundar T, Høye IM. Forskning i helseforetak - klisjé eller klinisk realitet? Tidsskr Nor Lægeforen 2002: 122: 2659-60. \\ 2. Lov om spesialisthelsetjenesten m.m. www.lov- data.no/all/nl-19990702-061.html (31.3.2010). \\ 3. Styringsdokument 2009 Helse Fonna HF. Bergen: Helse Vest RHF, 2009 \\ 4. Oppdragsdokument til Helse Vest RHF. Oslo: Helse-og omsorgsdepartementet, 2009. \\ 5. Mandat for regionale nettverk innen psykiatri og psykisk helse. Bergen: Helse Vest RHF, 2006.}

Manuskriptet ble mottatt 30.6. 2009 og godkjent 8.4. 2010. Medisinsk redaktør Are Brean.

\title{
Ikke glem oss kronikere
}

\author{
Nå diskuteres sykefravær så fillene fyker. Mange er engasjert, men kroniske pasienter \\ snakkes det lite om.
}

Jeg har en kronisk tarmsykdom, ulcerøs kolitt, som det som regel går veldig fint med. I høst ble jeg behandlet med en antibiotikakur for en luftveisinfeksjon, og det resulterte i oppblussing av kolitten. Jeg er tøffere enn toget og trodde at jeg skulle greie å kvele utbruddet helt på egen hånd. Jeg har like godt gangsyn som en muldvarp når jeg fortsetter å jobbe til jeg nesten stuper mens betennelsen blir verre. Da jeg endelig oppsøkte spesialisten, var jeg en hårsbredd fra innleggelse. Spesialisten jeg går til er helt fantastisk, og han huker tak i meg og holder meg fast til betennelsen gradvis slipper taket. Det trenger jeg, for jeg tenker at det hadde vært ganske deilig om jeg selv kunne slippe å ta kontakt når det braket løs. Tenk om jeg kunne blitt plukket opp helt automatisk når verden holder på å spore av? Men jeg er selv ansvarlig for å si ifra når det bærer galt av sted. Det er ingen andre som kan vite noe hvis ikke jeg sier ifra. Hallo - jeg er syk!

Og hva skal til for at jeg skal oppsøke legen og få hjelp? Jeg må være sikker på at det ikke er falsk alarm. Jeg må være sikker på at arbeidsgiver ikke blir belastet unødig hvis jeg blir borte en periode. Jeg må føle meg skikkelig dårlig. Og jeg må orke å ta initiativ. Alle disse må slå til. Det er veldig slitsomt hele tiden å være på tilbudssiden. For det er det det handler om. Jeg er ingen selger, så det å ta kontakt og si ifra om slikt passer egentlig dårlig for meg. Ikke misforstå. Jeg skravler som en foss og er visst veldig utadvent og alltid den som ordner opp rundt meg - for alle andre.

Legen min sykmeldte meg. Jeg tror han sa at jeg ikke skulle på jobb dagen etter. Nei, vel. Samtidig som jeg ble bedre, kom forstanden sigende tilbake. Sakte, men sikkert gikk det opp for meg at jeg hadde drevet med risikosport i noen uker. Jeg tror jeg går i boks når jeg blir syk - skjønner ikke helt at jeg er litt på etterskudd med å forstå symptomene. Her har jeg virkelig noe å jobbe med.

Arbeidsgiver og jeg har søkt om unntak fra bestemmelsen om arbeidsgiveransvar. Og det er innvilget. Det innebærer at arbeidsgiver får tilbakebetalt sykepenger fra NAV fra dag 1 hvis jeg blir syk. Utrolig godt for meg å vite at arbeidsgiver i hvert fall slipper en slik økonomisk belastning når jeg har så dårlig sammensatt arvemateriale at jeg blir syk på denne måten. Når jeg nå er tilbake i $100 \%$ jobb, er jeg også så heldig at jeg kan velge å arbeide hjemmefra når dette passer best for meg. Alle som vet litt om ulcerøs kolitt, kan vel skjønne at morgenen og formiddagen kan være barsk om sykdommen er i en fase med litt aktivitet. Da er det fint å ha sofakontor med eget toalett rett i nærheten.

Jeg blir tatt godt vare på. Men ikke glem oss kronikere - nå som dere skal stramme inn på sykefraværet.

\section{NN}

Oppgitte interessekonflikter: Ingen 